\title{
Nepalese Journalists' Democracy Building Roles and News Coverage Practices
}

- Sudarshan Prasad Dahal

This is a case study of Nepalese journalists' perceived democracy building roles and their news coverage practices. The content of two national daily newspapers, Kantipur and Nagarik, was selected to analyse to know the consequences whether Nepalese journalists' news coverage practice reveals their perceived democracy building roles. Existing literature reveals that Nepalese journalists perceive their roles for democracy building as disseminator, populist mobiliazer, interpreter, and adversarial, respectively. The findings of this study suggest that Nepalese journalists give more importance to provide accurate and timely information, and interpretation of complex problems in terms of Constituent Assembly (CA) related issues in their coverage. They give less importance to investigating statements and claims made by the governments or political parties, as well as provide ordinary people a chance to express views to public affairs in news coverage for enhancement of democracy. It is noted that changing Nepalese political situation from less democratic authoritarian ruler to republican democratic system and increasing number of media landscape might be the influenting factor of changing journalists' perceived democracy building roles reflection in their coverage.

\section{Introduction}

The way in which journalists define their jobs will affect the content they produce (Shoemaker and Reese, 1996, p. 97). Reporters, who saw themselves as neutrals write the least fair and comprehensive stories, and who saw themselves as midway between the extreme neutral and the extreme participant, write the most objective and accurate stories (Starck and Soloski, 1977). 
In a comparative research on Brazilian journalists role perceptions Herscovitz's (2004) found that Brazilian journalists give more importance to analyse and interpret governments' claims in their coverage. Furthermore, they also want to disseminate accurate and timely information for public good. Their least preference was to become adversaries to government officials and the business as well as to give an opportunity to a voice to the ordinary citizens.

Similarly, Mwesige's (2004) notes that Ugandan journalists are working with under conditions that pose major legal, political and economic limitations on their journalistic freedom. But, journalists perceive their roles similar to the Western countries (Mwesige, 2004). He further states that, Ugandan journalists highly value the western journalistic functions of information, analysis and interpretation and investigation of official claims. Furthermore, Ugandan journalists also show strong support for 'populist mobilizer' functions such as giving ordinary people voice and setting the political agenda.

Ramprasad and Kelly (2003) had investigated influencing factors that shape journalists role perceptions in the third world context such as Tanzania and Nepal. Journalists of Tanzania were giving more importance to information dissemination role following by interpretative/investigative role. In Nepalese survey study they found that Nepalese journalists perceived disseminating accurate and timely information as well as investigating governments' claims and statements, were the most important journalists' perceived roles.

Against the background, this research intends to focus on whether journalists' perceived democratic building roles correspond in their news coverage practices for strengthening democracy. As a case study, this paper explores to what extent Nepalese journalists'democracy building roles reflects their coverage. The main purpose of this research is to acknowledge professionalization of Nepalese journalists in such context where very little literature reveals the exact situation of journalism practices. This study analyzed media content to 
know journalists democracy building roles in their coverage practices in Nepal.

\section{Relationship between Journalism and Democracy}

Information dissemination is an essential pre-requisite component of democracy for people's participation in decision making process. Accountable government does not only provide the access to public on decision making process, rather monitor the diverse source of powers. The government assures the public promoting norms and procedures of democracy to solve the problems that occur in the democratic process (Timothy E. Cook, 2005:116).

Schudson (2008) describes seven functions that journalism should have to play in ideal democracy. These functions includes 1) informing the public; 2) investigating the activities of power holders particularly to the governments; 3 ) analysing the complex world situation; 4) sharing social experiences with scattered public; 5) providing forum for public discussions ; 6) mobilizing people for acting democratic practices; and 7) publishing representative democracy (Pp. 11-26). Thus, democracy expects some important roles that journalists should perform in the democratic society. Those roles includes as educator, interpreter, investigator, information provider, mobilizer and watchdog (Schudson, 2008).

However, it is apparent that democracy needs several roles of journalists for fuller democracy. Whether journalists also perceived such roles as democracy expect from them? Some scholars like Janowitz (1975) notes that journalists' role perception might be varies according to time and context.

\section{Journalists' Role Perceptions}

Johnstone, Slawski and Bowman (1972) identified two roles of journalists as neutral observer and the participant for democracy building process. In neutral role, journalists see their function as simply to transmit the events what they see to the public. They 
value speed of communication, accuracy, and objectivity. Put differently, journalists believe that they are the 'impartial transmission link dispersing information to the public' (Johnstone, et al.1976, p. 114). In participate role journalists acknowledge that they cannot be completely objective (Skewes, 2007). Their subjective judgement determines what goes in the lead and what goes in the fourth paragraph (Johnstone, et al.1976).

Janowitz (1975) notes that there has been a shift over time in terms of journalists' perceived roles that they believe they serve in democratic society. Their role model changed from one of detachment to one of involvement, and the advocate journalist strives for fairness and social justice (Skewes 2007). Thus, context is important to evaluate journalists' roles perceptions.

There are several roles conceptions that journalists perceived. In their survey of working journalists in the U.S., Weaver and Wilhoit (1996) identified four different role conceptions held by reporters. Accordingly, information provider role priorities their duty is to get information to the public as quickly as possible. Journalist's interpretive role inspires them to investigate stories and provide their readers with analysis of complex issues. Similarly, adversarial encourages a sceptical, perhaps even cynical view towards the power - especially those in government. Finally, populist mobilizer holds that journalists need to help develop public interests, set the public agenda, and provide a forum for ordinary citizens to express their opinions. In sum, journalists or meda workers are the ultimate gatekeepers who deserve to control the free flow of information.

\section{Gatekeeping Theory and Practices}

Gatekeeping refers broadly to the process of controlling information as it moves through a gate or filter and is associated with exercising different types of power (e.g., selecting news, enforcing the status quo in government authorities, mediating between professional and ethnic groups, brokering expert information). Scholars agree that items, those bits of 
information that are rejected or selected, shaped and scheduled, are the focus of all gatekeeping studies (Preston, 2009).

David Manning White (1950) for the first time examined how a certain, Mr Gates, the wire editor of a morning newspaper in the USA's Midwest, set about rejecting or selecting news stories over the course of a week. White sought to understand why and how this individual wire editor made the 'complicated' set of decisions in selecting certain news stories sent by the news agencies whilst having to reject most of those received. He found that about one third of the time, Mr Gates rejected stories based on his personal evaluation of the merits of the item's content, especially whether he believed it to be true or not. White concludes that journalist's role of subjective and individual factors influence in shaping the news selection process.

There has been several research conducted to evaluate the influencing factors that control the free flow of information. Newspaper publishers by policy, or, with other covert and consistent orientations' of a paper's news and editorials, they revolved primarily around partisan, class, and racial divisions (Breed, 1955). Journalists are susceptible to pressure from groups and individuals with power to affect them, their organizations, and their firms (Gans, 1979).

News production is part of wider system of social relations and normative controls (Gieber and Johnson, 1961). Sigal (1973) found that U.S. government officials, the 'knowns' accounted for almost one-half of all the sources cited in the sample of page-one stories of the New York Times and Washington Post. The 'unknowns' were given a fifth of the space, and include protesters, victims, violators, and other ordinary people.

Although many researchers examined news sources as influences on media agenda, some scholars have focused on what factors make journalists seek out particular sources. Studies have identified source credibility, accessibility, prominence, knowledge, and deadline pressure as some of the 
influential factors (Flynn, 2002; Paletz and Entman, 1981; Powers and Fico, 1994; Shoemaker and Reese, 1996). In their study of variables that affect reporters' decisions on source usage. Powers and Fico (1994) found that an individual reporters' judgement was the principal influence on the media's selection of sources. Journalists prefer government sources because they are generally available (Paletz and Entman 1981).

News value is another factor that determines news making process (Donbach, 2004). Proximity, timeliness, and visual availability were three important criteria for the editors for the selection of stories with high impact (Buckalew, 1969). Other influencing factors were time span, intensity or threshold value, clarity/lack of ambiguity, cultural proximity or relevance, consonance, unexpectedness, continuity, composition, and socio-cultural values of the receiving society or gatekeepers (Galtung and Ruge, 1965). Deviance and social significance were two primary news selection criteria for journalists around the world (Shoemaker and Cohen, 2006).

A final category of theories explains news selection with forces outside news organizations. However, scholars argue that market economy influence the news selection process (Hamilton, 2004); there is not similar view that which news journalists cover as a news story. Some Marxists treat journalists as the public-relations agents of monopoly capitalism (Molotch \& Lester, 1974). Likewise, ideological determinants believe that journalists align the news to the political ideology of those holding power in the country (Altschull, 1984). Cultural theorist extend this by viewing journalists as selecting news which accord with the values of national culture (Gitlin, 1980). A related approach centres on the audience in that people get news as they deserve (Bauer, 1964). Another type of externally centred theory suggests that news is shaped above all, by sources on which journalists rely; or to create what they call 'public events' and to gain access to journalists (Gieber, 1960, see also Shoemaker and Reese, 1996). 
However, gatekeeping research is becoming complex and radically changing; Shoemaker and Reese (1996) proposed a comprehensive framework for analysing various influences on media content. The social system level looks upon the culture to evoke the surrounding atmosphere of prevailing ideas, ideologies and discourses that permeate journalists' working environment and news content, including its language, forms and 'feel' in a given societal context. In the social institutional level, extra-media influences the news such as advertisers, audiences, and government control. Journalists' choice of sources, to some extent, is their selection of news. With respect to influences at the organizational level, news is the result of a combination of decisions by journalists within news organizations and the influences from media owners, editorial policies, budget constraints, social control within the newsroom, and organizational goals. At the routines level, news production is based on a pre-established and generalized set of practices. At the individual communicator level, news content is influenced by journalists' characteristics, personal and professional backgrounds, personal attitudes and professional roles perceptions and ethics.

\section{Individual Level of Analysis}

Two alternative paths project news selection as 'highly subjective' and 'reliant upon value-judgements based on the gatekeepers' own set of experiences, attitudes, and expectations (White, 1950) and organizational role and their power or status in an organization (Shoemaker, 1991). Furthermore, Shoemaker and Reese argue that

Journalists' characters (such as gender, ethnicity, and sexual orientation) and their personal backgrounds and experiences (such as religious upbringing and their parents' socioeconomic status) not only shape the journalists' personal attitudes, values, and beliefs, but also direct the journalists' professional backgrounds and experiences (such as whether the communicator goes to journalism or film school). These professional experiences (including those from 
communication job) then shape the journalists' professional roles and ethics (1991, p. 65).

Figure 1 Two Alternative Paths that Infuence Media Content

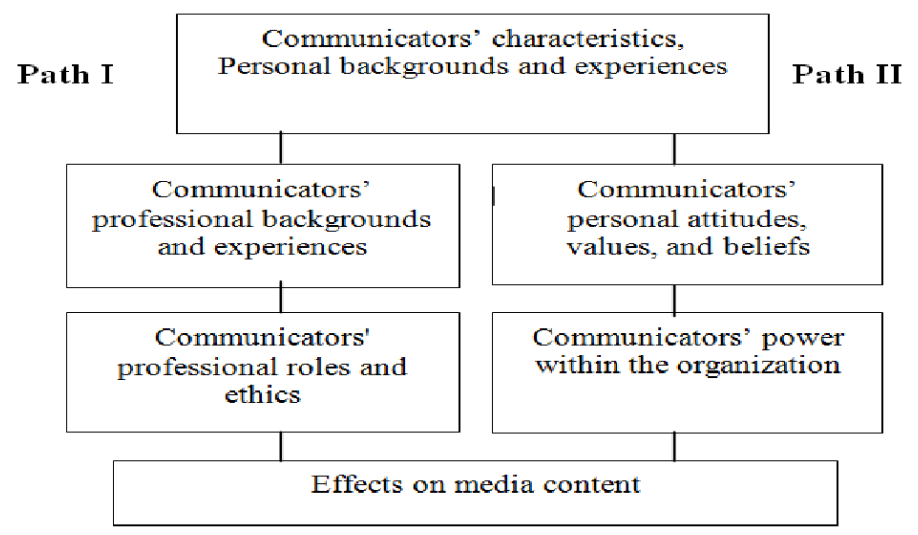

Source: Mediating the Messages (Shoemaker \& Reese, 1991; see also McQuail, 2000, p. 267)

The effect of journalists' personal attitudes, values, and beliefs on mass media content is indirect while their professional roles and ethics have a direct effect (Shoemaker, 1991, p, 61). However, Weaver and Wilhoit's (1986) found that journalists' demographics like 'gender, age, income, and a host of other factors were unrelated to perceptions of what defines news' ( $p$. 127); several research show a mix results of correlation between journalists' demographic characteristics and its influence on news making process.

However, the findings from the research on gender are inconsistent. Ross (2004), for example, discovered that female journalists do not believe that their journalistic practice differ much from those of male journalists. That conclusion is consistent with a finding from Peiser (2000), who examined the issue agendas of male and female journalists. He found that their agendas were 'not too dissimilar'. Weaver and Wilhoit (1996) study of American journalists concluded that women tended to rely more heavily on female sources than male 
reporters and that their stories were more likely to be about social problems. Women journalist's presence in news media organization shaped coverage of women's issues (Farley, 1978; Goodrick, 1991). Hence, gender participation in the news organization is an unreliable predictor of differences in news judgement (Chambers et al., 2004).

Journalists' professional and ethical orientations are primarily shaped in their occupation or by their professional education. Media workers who have a communication college degree produce content with different characteristics than do those with other majors (Shoemaker and Reese, 1996). However, there is no indication that major in journalism or communication is associated with job stability or job satisfaction, Weaver and Wilhoit's (1986) study of American journalists found that formal training in journalism is becoming a necessary condition for entry into the U.S. news media.

Journalists' professional and ethical orientation factors can be examined through how journalists' gain knowledge about professional norms, values and practices. Many relevant researches suggests that journalists' professional values and ethical orientations tend to be formed or shaped by socialization processes mainly located in work-based experience and learning by doing (Breed, 1960).

Journalists' ethical roles influenced them to follow the moral values based on principles of right and wrong (Altschull, 1990, p. 357). Many news media published standards governing how their staffs should operate (Black, 1992). Society of Professional Journalists Code of Ethics state that the duty of journalists is to serve the truth. The Ethics further state that it believes the responsibilities of journalists is to carry obligations that require journalists to perform with intelligence, objectivity, accuracy, and fairness. But, Peterson et al., (1984) study on newspaper business editors' attitudes towards capitalism was as a way of explaining the alleged and business sentiment of the press. 
The research evidence suggests that the potential scope for individual journalists to exert personal influence tends to vary according to the profile and status of the media worker, the type of media organization and/or genre (Preston, 2009). The relevant research suggests that non-news genres tend to provide greater scope for expressing personal beliefs (McQuail, 2000). Similarly, the degree of personal influence of journalists includes the extent to which the media organization enjoys a healthy commercial and financial record (Preston, 2009). Highprofile 'stars' or celebrities tend to enjoy relatively privileged degree of freedom to express personal opinions and beliefs compared to the rank-and-file, even within news organizations (Shoemaker and Reese, 1996).

Nevertheless, there are not similar views among scholars regarding the relationship between journalists' personal attitude, values, and beliefs and its effects on the news coverage. Some scholars say that journalists' personal attitude does not necessarily translate directly into their behaviour (Robinson, 1983). For instance, Robinson's 1983 study of journalists in the United States reported that the supposedly liberal journalists treated Democrats worse than Republicans. On the other hand, other scholars believe that the influence of personal attitudes, values, and beliefs is even less direct. These critics suggest that journalists' 'world-views' - their perceptions of social reality - may influence their work. Shoemaker and Reese (1996) suggest that journalist' personal attitudes, values, and beliefs on content depend on newspapers' specific policies about potential conflicts of interest (p. 81).

However, the Ethics Handbook recommends basic guiding principles such as 'seek truth and report is as fully as possible; act independently; and minimize harm' (Gersh, 1992); scholars agree that conflict of interest can arise from the journalists' assignments. For example, crime reporters must gain enough trust from their police sources to elicit cooperation, and such cooperative relationship could create a conflict of interest in stories about wrongdoing in the police department (Shoemaker and Reese, 1996). Crime reporters 'were obliged to defend and 
promote the interests of police unless they can be clearly shown to be in conflict with the interests of the public (Chibnall, 1981).

Research shows that journalists' professional values tend to influence journalists to follow their roles (Shoemaker \& Reese, 1996). Weaver (1998) survey of the USA-based working journalists reveals that 'objectivity' as the single most important professional value. European journalism practices suggests that objectivity as a core value is often seen to match up closely with the neutral model of journalism and the notion of 'balanced' reporting (Preston, 2009). Scholars suggest that the preference for 'objectivity' also neatly matches the master logic of commercial media organizations, as partisanship might put off the potential appeal to advertisers or audiences (McManus, 1997; Weaver, 1998; McQuail, 2000). However, professional values influenced journalists role in both commercial and public media system, objectivity is the core value of the journalists.

Keeping the public-up-to-date with news/information is another key value that journalists tended to follow (Shoemaker and Reese, 1996). Another much cited journalistic value is investigative journalism alongside the 'watchdog' role (Weaver, 1998). The provision of analysis of events also features as a prominent value for journalists in many countries, but it seems to be relatively less important for journalists in the USA (Weaver, 1998, p. 466).

Journalists' professional values, attitudes and practices, including ethics, are increasingly affected by their working realities. As news organizations become ever more embedded in commercial concerns and pressures, journalists' organisational life increasingly becomes shaped by economic concerns (Berkowitz \& Limor, 2003; Hallin, 2000). However, other authors take a more favourable stance in relation to the role and potential influence of formal codes of ethics. For example, Belsey and Chadwick (1995) start from the observation that the question of media quality is important, given the close connections between media and liberal 
democracy. They argue that the legal route to media quality is necessary, but not sufficient to ensure quality: it 'needs to be supplemented by the ethical route, understood as a competence to deploy ethical consideration in professional practice' ( $\mathrm{p}$. 461).

Journalists' age and size of news media might vary in their ethical decisions (Weaver and Wilhoit, 1991, p. 128). In their study, only 5 per cent of journalists could see any justification for revealing a confidential source, whereas 20 per cent approved of claiming to be someone else in order to get a story. Just one-fourth of journalists approved of paying people for confidential information or using personal documents such as letters without permission. Mound half of journalists thought that badgering unwilling informants or using confidential business or government documents without authorization are justified. About two-thirds of journalists accepted going undercover as an employee of a company in order to gain inside information about it. Older journalists were less likely to approve such practices; journalists working for large organizations were more likely to approve them. Furthermore, Weaver and Wilhoit (1991) note that about three-fourths of journalists credited newsroom socialization or their family upbringings with influencing their ethical standards. Half or more said that fellow journalists or college professors had influenced them (p. 135).

Organization structure and role perception is another influencing factor in their coverage practices. Journalists working with large staffs tended to embrace the interpretive and adversarial roles. One the other hand, Journalists working in smaller organizations were likely to embrace the populist mobilizer role (Weaver \& Wilhoit, 1991). 


\section{Nepalese Context and Research Questions}

\section{Early History}

The history of Nepalese politics and the Nepali journalists have parallel ramification. During Rana Period (1854-1951) there was only one print media 'Gorkhapatra' (1901). It was a stateowned newspaper under the control of the autocratic Rana family regime. Function of journalists in this half century period (1901-1951) was basically to disseminate government notices and information (Malla, 1983). With the establishment of democracy 1951, numerous print media as well as electronic media for the first time 'the Radio Nepal' (1951) aired in the country. However, the relationship between the government and the journalists in this open democratic political system marked the tense relationship; democratic government blame journalists not being honest to perform advocacy role of the government decisions. Rather, journalists performed a responsible societal role in the first time in Nepalese society.

\section{Panchayat Era}

During Panchayat Era (1960-1990), government has restricted citizen's political freedom and the press freedom. Many newspapers were shut down in authoritarian system. Journalists were obliged to either support the Panchayat system or close the operation of the news production. 'Self-censorship' was to escape the financial and personal consequences of defiance including denial of state subsidies and newsprint quotas as well as imposition of jail terms (Savada, 1993).

Nepalese politics and journalists' situation changed after 1980 Referendum. After the referendum, media's restriction gradually replaced with Liberal Press and Publications related legal provision that removed most of the past restriction on the press. Journalists' limited freedom divided them to start mission oriented journalism (Pokharel and Koirala, 1995). Prodemocratic journalists supported the opposition parties struggle 
for establishment of multi-party democracy and gave voice to their leadership (Paudyal, 1995).

\section{After Restoration of Democracy}

People's successive democratic movement against Panchayat system established multi-party democracy in 1990. Constitution of Nepal 1990 guaranteed press freedom restricting the cancellation of newspaper registrations, censorship and newspaper closures. National Communication Policy of 1992 promoted to establish private print and broadcast media.

However, Constitution of Nepal 1990 ensured people supremacy under the constitution; public's political rights and press freedom stroked several times because of the undemocratic move of political actors (Thapalyal, 2006) in the multi-party democracy. Monarchy, parliamentarian parties, and Maoists were the main political actors who played a crucial role for suppression of political rights and the right of freedom of expression of Nepalese people. Some Ministers of democratic government directly took initiation for granting licence for operating media organization. During Maoists insurgence (1996-2006) around 17 thousands innocent people including 24 journalists died during the period. Many media organizations were closed down due to threat and kidnapping of journalists from both people's militia and the government's security personal. Likewise, then King Gyanandra's royal coup in February 1, 2005, journalists loosed press freedom (Hachhethu, 2007).

Nepal's democracy in real sense became a ruling tool for every political actors - ruling Political Parties, revolutionary Maoists, and the King - rather than governing people. Political parties were not responsible actors under democracy, because inter and intra party competition for power politics encouraged them to manipulate media power discarding implementation of media strengthening law. The Maoists brought further instability and their violent activities not only destroyed physical infrastructure of the nation also became the cause of assassination of media 
workers. Finally, the King took advantage of the chaos to take over the reins of power - seizing press freedom in the name of restoring democracy. These triangular forces have been struggling against each other to gain ruling power instead of establishing federal state structure and moreover they were diminishing the norms of editorial independence.

Very recently, People's Movement II (2006) succeeded to change 240 years long Hindu Kingdom into republican secular state. Constitution Assembly Election of 2008 not only paved the way to make a secular, federal, and inclusive republican constitution in the country, rather assisted controlling assassination of journalists in the name of civil war (19962006), when almost two dozen journalists were killed (Adhikari, 2008). Many observers describe that Constitution Assembly members as well as other democratic align institutions including journalists were unanimously contributing for drafting constitution such as providing space for politicians, and covering issues and agendas in the news.

\section{Perceptions on Nepalese Journalists' Professional Role}

Ramprasad and Kelly's (2003) case study provides Nepalese journalists' professional profile and theirs role perceptions, such as information dissemination, investigation and activist role for enhancement of democracy. Theirs survey reveal Nepalese journalist perceived importance media roles in 16 items ideas scale in the four factors in the following hierarchies: the mean score of the public advocate factor (investigate leaders and give voice to people) is 1.63; of citizen education (inform and educate public on political matters) 1.74; of culture, (entertain, provide cultural fare) 1.75; and of development journalism (positive coverage of leaders, country, events) 2.3 (the statements were factor analysed using principal components analysis with five point scale varimax rotation).

Furthermore, among single items, Ramprasad and Kelly (2003) rated the item, for example, as most important is accurate and timely information, among all 16 items scored high that mean 
point scale is 1.25; following by give ordinary people a chance to express views to public affairs, 1.48; provide analysis and interpretation of complex problem, 1.61; and, investigate claims and statement made by the governments, 1.79 (for the means, low score equals greater importance and the scale ranges from 1 to 5$)$.

Ramprasad and Kelly (2003) noted that Nepalese journalists believe that the media are playing an activist role in development, advocating development matters, presenting educational programmes, covering the poor, women's issues, and rural areas, being socially responsible and encouraging people. They also note that Nepalese journalists believe that 'advocacy and activism on developmental issues', giving 'priority to developmental news', working for 'social (development) and the country's development', discussing 'the development issues affecting ordinary people primarily', being the spokesperson of the poor people of the country and giving 'preference to such news broadcasts that would help improve the condition of the poorest class' (p. 306)

Ramprasad and Kelly (2003) noted that Nepalese journalists give importance for fostering newly democracy, giving importance to the following functions of the journalism as - to inform, educate, disseminate, and advocate. In terms of journalists' role perceptions Ramprasad and Kelly (2003) asked several questions about news value judgement and its correlation with the perceived roles. Along with other news item variables, they analyzed journalists' perceived roles with the following variables such as information dissemination role with providing accurate information in a timely manner; interpreting role analysing with complex problem; watchdog or investigative role investigating claims and statements made by the governments as well as populist mobilizer or activist role giving people a chance to express views to public affairs (Ramprasad \& Kelly, 2003).

On the other hand, journalist Code of Conduct, 1998 ${ }^{1}$; and, Code of Journalistic Ethics $2003^{2}$ are guiding norms and values 
of Nepalese journalists. Accordingly, the ethics expect from journalists that faithfully exercise professionalism of a high order so as to be responsible, accountable and reliable, and dedicated to the basic norms and principles of journalism (Code of Journalistic Ethics, 2003).

In such a context, however, the available literature show that Nepalese journalists give more importance to democracy building roles such as disseminator, interpreter, investigator and populist mobilizer (Ramprasad \& Kelly, 2003; see also Weaver \&Wilhoit, 1996); yet it is unclear that to what extent they project their perceived roles in the news coverage. Whether Nepalese journalists' coverage corresponds with their role perceptions? To know the empirical answer on these matters, the present study intends to explore the following research questions

\section{Research Questions}

R.Q. 1 to what extent the news item that relates to analysis and interpretation of complex issues can be found in the coverage of national dailies of Nepal.

R.Q. 2 to what extent the news item that relates to providing accurate and timely information can be found in the coverage of national dailies of Nepal.

R.Q. 3 to what extent the news item that relates to investigating claims and statement made by the governments or political parties can be found in the coverage of national dailies of Nepal.

R.Q. 4 to what extent the news item that relates to giving ordinary people a chance to express views to public affairs can be found in the coverage of national dailies of Nepal.

R.Q. 5 what is the priority order among four news item variables (as accurate and timely information; give ordinary people a chance to express views to public affairs; provide analysis and interpretation of complex problem; and, investigate claims and statement made by the governments) that Nepalese news media such as newspapers reveal in their coverage. 


\section{Methods}

The research method employed in this study was content analysis. Content analysis is defined as 'a research technique for the objective, systematic, and quantitative description of the manifest content of communication' (Berlson, 1952, p. 18). Krippendorff (2004) defined content analysis as a research technique for making replicable and valid inferences from data to their context. Historically, many mass communication studies have examined the content of mass media using the method of content analysis (Perry, 2002).

Hence, content analysis was used in this study to provide an objective and in-depth description of Nepalese journalists' perceived roles correspondence in their news coverage. This method was also selected because of its strength for examining media content.

The purpose of this study was to investigate Nepalese journalists' perceived democracy building roles in their news coverage. News contents were selected on the basis of newspapers' quality, circulation, language and availability criteria. Those newspapers which were available on the on-line version with coverage of Constitution Assembly news was availability criteria. The news relate to Constitution Assembly (CA) was chosen to identify the pattern of Nepalese journalists' democracy related news coverage practices.

Constitutions Assembly (CA), in Nepalese context, is an apex body of political elites who are represented from direct (first past the post - FPTP) election and proportional election; and members nominated by the decision of the Cabinet. The main objective of the formation of the CA is to prepare the draft constitution and ratify it by addressing the people's spirits that accounted during People's Movement II for maintaining the long-term peace in the country. Thus, the Constitution Assembly issue was not only important to make new democratic constitution rather it was one of the major task for $\mathrm{CA}$ members to include the political issues like federalism, 
secularism, social inclusion, minorities, ethnic groups and human rights and so on as par people's spirits in forthcoming constitution. Hence, it can be noted that the issue of Constitution Assembly is an important case study that is associated with establishment of democracy in the country. As a case study, the coverage pattern of $\mathrm{CA}$ related issues might assist to understand journalists performing democracy building roles in the country.

For quality and circulation; Press Council of Nepal's report 2008 was followed. Accordingly 'A' grades two independent leading national dailies- the Kantipur Daily and the Nagarik Daily - were selected. Ideologically both newspapers do not correspondence direct alignment with political parties; however, it can be observed that both newspapers are inclined towards liberal democracy. Wider circulations of these news media houses considered as a role model for inter media agenda-setting roles in the country.

The Kantipur daily is a broadsheet of Kantipur Publications Pvt. Ltd. That established after the restoration of democracy 1990. As a nationwide circular newspaper, its national editions publish from different four places - Kathmandu, Biratnagar, Pokhara and Nepalgunj - and its foreign edition publish from Doha, Qatar in Nepali language. Under the Kantipur Publication House, there are several other publications, for instance, the Kathmandu Post (English daily), Nepal (Nepali weekly magazine), Naari Munch (Nepali Monthly Magazine), Saptahik (Nepali Weekly); as well as the Kantipur F.M. and the Kantipur Television.

Unlike the Kantipur Daily, Nagarik Daily is a quite young publication of Nepal Republic Media Pvt. Ltd. which was started in 2008. As a nationwide circulation the media house has been publishing Nagarik from different parts of the country i.e. Kathmandu, Biratnagar and Nepalgunj in Nepali language and My Republica, in English language; though it has very short history of establishment. 
In terms of the language criteria, the Nepali language was chosen because the purpose of the study was to evaluate Nepalese journalists' perceived roles in their news content. Thus, it is assumed that any professional journalist who covers news in his/her own native language can transform content perfectly in line with their perceived roles. On the other hand, it is also assumed that democracy related news which published in national language daily may reach into mass audiences and assist them to take decision in line with Media agenda setting roles (McCombs and Shaw, 1972).

Based on these criteria, two national vernacular dailies' - The Kantipur Daily and the Nagarik Daily - on-line version news items were retrieved for analysis. Constitution Assembly related news items that published in between $1^{\text {st }}$ March, 2010 to $15^{\text {th }}$ March, 2010 were collected.

The coverage date ( $1^{\text {st }}$ March, 2010 to $15^{\text {th }}$ March, 2010) was selected because this is the high time of discussion of different political issues that had to be incorporated in the forthcoming constitution. Thus, this is the prior three months mandatory period for promulgating new constitution (Initially two years mandatory deadline of $28^{\text {th }}$ May, 2010 has provided by CA Election 2008). Previously, it was assumed to cover one month news stories for the study but our prior observation about political news flow in Nepalese newspapers was different. There were 180 news items were related to political information during 15 days period ( $1^{\text {st }}$ March, 2010 to $15^{\text {th }}$ March, 2010). It was assumed that the number of news items (total news 180) were sufficient to investigate the coverage pattern of Nepalese news media for manually assisted work. Furthermore, it was also assumed that the journalists who were working with highly circulated private national newspapers could represent the trend of Nepalese journalists' news coverage practices.

\section{Variables}

To examine the research questions, relevant variables and coding categories were developed. Variables and categories are 
an important part of content analysis because content analysis is based on defining variables and looking for associations among them (Neuendorf, 2002).

Each news item was tested with four news value variables. Accordingly, 1) providing analysis and interpretation of complex problem; 2) accurate and timely information; 3) investigating claims and statement made by the governments; and, 4) giving ordinary people a chance to express views to public affairs. These variables were selected to answer research questions of the study in order to create a better understanding of Nepalese journalists' perceived democracy building roles in their news coverage.

Based on work conducted by Weaver and Wilhoit (1996), and Johnstone, et al. (1975); this study also followed code book's operational definition of each variable for contextual clarity intending to capture journalists' role perceptions in news coverage in the following ways. Accordingly, despite reporting straightforwardly; the news stories which analysed a situation, evaluating or explained the issues and agendas of Constitution Assembly such as secularism, federalism, ethnics, minorities, women, integration of Arms groups and peace process as well as government formation were criteria for interpretation of complex problem. In other words, analysing such issues and agendas rather than just a piece of reporting was considered on this category.

Similarly, the news that covered the immediate events or incidents referring sufficient sources (by-line or other government or reliable sources rather than anonymous piece of article) was categorized in the accurate and timely information. For investigating reporting the news that covered both political parties such as ruling and oppositions' claims and statements with background information as well as analyses with various sources were coded. Because the issue of constitution making was the concerning matter for all political parties along with the governments. Finally, the news source or the news that include the story of ordinary citizens or other minorities or pressure 
groups were categorized in giving ordinary people a chance to express views to public affairs variable in news coverage.

\section{Coding Categories, Code Book and Reliability Test}

Coding is 'the process whereby raw data are systematically transformed and aggregated into units which permit precise description of relevant content characteristics' (Holsti, 1969, p. 94). In the data coding process, a unit of analysis is recorded, identified, and linked to the conceptual categories. The code book was designed to provide the rules for assigning a coding unit of each category. The coding sheet and the coding instructions were documented in a systematic way that any researcher can follow it for further investigation.

The coder followed the following steps - first, it was coded for title of the newspaper, exact date of publication, title of the news items and so on. Second, each news items which were selected for analysis were coded with the best judgement of the coder on the presence and absence criteria of the above mentioned four variables each.

Equal nominal level of measurement was adopted for news item checking. The coding process was done in such a way that, if the news that attributes any one of aforementioned variables that counted 'yes' type for this particular news item variables; similarly if the news that do not have any attributes of these variables that counted 'no' type category for this particular news item variables. For instance, in regard to the variable: accurate and timely information; if the news possesses with the attribution as defined above for accurate and timely information, than the news is coded ' 1 ' for 'yes' type and if the news do not possesses any attributes as defined above then the news is coded ' 2 ' for 'no' type correlation for this accurate and timely information variable.

In terms of reliability test, one graduate Nepalese student was assigned. The student was chosen because the present study was designed to analysis news content that published in Nepali 
language. It was instructed the coder to follow the code book and whenever confused arise the author personally assisted him for clarification in terms of the code sheet. News stories were systematically selected because it was probable that minor presence variables of the news stories might be omitted. Thus, for checking the reliability test, 20 per cent news stories were selected considering that at least 10 per cent of each variable should be represented for reliability test. On this regard, total 36 news stories were selected. Average inter-coder reliability was $82 \%$, $(\mathrm{r}=.82)$, ranging from $80 \%(\mathrm{r}=.80)$ to $84 \%(\mathrm{r}=.84)$ using Holsti's formula measuring the percentage of agreement, and differences were reconciled throughout the coding process. Reliability efficient of .80 or greater is acceptable in most situations.

\section{Unit of Analysis}

In terms of the articles selection, each news items were selected manually. The news items were identified with inclusion and exclusion basis of consecutive variables. That news which contained one of the following references as the "Constitution Assembly' or 'New Constitution', or 'Constitution Making' were included. To choose these key words, it was assumed that constitution related all political news items can be covered with these three key words. According to the criteria 106 news were selected from the Kantipur Daily and 74 from Nagarik Daily during $1^{\text {st }}$ March to $15^{\text {th }}$ March, 2010. These news items are easily available content in these newspapers' homepage archive section, where hyper linked news heading can link for full texts. However, editorials, op-Ed pages, and letter to editors' pages were excluded. Because, these sections are mainly known as opinion pages and, in general, there is practice in Nepal that, besides journalists, any freelancer or other external sources may write their opinion on these sections.

\section{Results}

Each news story was analysed using a quantitative content analysis. Two national vernaculars dailies - the Kantipur Daily 
$(\mathrm{n}=106)$ and the Nagarik Daily $(\mathrm{n}=74)$ - altogether 180 news stories regarding the issue of Constitution Assembly (CA) between $1^{\text {st }}$ March to $15^{\text {th }}$ March 2010, were analysed. Each news story was examined on the presence and absence category on the following four different variables as 1) providing analysis and interpretation of complex problem; 2) providing accurate information in a timely manner; 3 ) investigating claims and statements made by the governments; and 4) giving ordinary people a chance to express views to public affairs. Previous research had identified those variables as the common items that Nepalese journalists perceived media roles for democracy building process in Nepalese context (Ramprasad and Kelly, 2003).

First research question was to investigate to what extent Nepalese journalists give importance their perceived roles in terms of providing analysis and interpretation of complex problem in their news coverage. The results show that Nepalese journalists provide analysis and interpretation of complex problems in the coverage covering CA related issues and agendas interpreting complexity of current events and incidents rather than reporting only. Examined news content shows that $65 \%$ news stories are providing analysis and interpretation of complex problems. The result is also consistence with the previous survey of Nepalese journalists of Ramprasad and Kelly (2003). Their survey found that Nepalese journalists give the second highest importance i.e. 1.61 mean score point out of five scale ratings for democracy building related items providing analysis and interpretation of complex problems.

Second research question was to investigate to what extent Nepalese journalists provide accurate information in a timely manner in their coverage. The study examined the news coverage content whether the news is covering current issues or events in a timely manner as well as covering news with appropriate sources was investigated. Here appropriate sources mean that news which mentioned government sources or other non-government organizations, pressure groups as well as party leaders and minority groups and so on rather than anonymous 
sources. The findings show that $67 \%$ news is covering with accurate information in a timely manner. The result is also consistent with the previous findings of Ramprasad and Kelly (2003) survey of Nepalese journalists' role perceptions where 1.25 mean point scale was captured out of five level point scales. It is interesting that, similar to this study the variable providing accurate information in a timely manner also had captured the highest ranking in Ramprasad and Kelly's survey study. 120 news items out of 180 is captured in the present study and the figure can be explained consistent with the previous study on this variable.

Third research question was to analyse the news item that investigate the claims and statements made by the governments. Both opposition and ruling political parties leaders statements and claims was examined in this variable because the research study was designed to analysis the CA related issues which was a common factor for all political parties or representatives who are representing in the Constitution Assembly of Nepal. The results show that $29 \%$ news items were captured in this variable. Ramprasad and Kelly's (2003) survey of Nepalese journalists' perceived democracy buildings roles related investigate claims and statements made by the government was found 1.79 mean score point in five level scale point analysis. However, Ramprasad and Kelly's study reveal Nepalese journalists' give more importance to investigate claims and statements made by the government; the present study captured only 53 news item out of 180 which is inconsistent in importance rank order among four variables to previous survey study of Ramprasad and Kelly (2003).

Fourth research question was to investigate to what extent Nepalese journalists give ordinary people a chance to express views to public affairs. Here, ordinary public means those people or organization that represent ordinary citizens, minorities and ethnic groups. The research examined the news coverage related to Constitution Assembly and found that $24 \%$ news items were giving space to express ordinary citizens' views. The variable was captured 1.48 mean point scale out of 
five level scales in previous Ramprasad and Kelly's (2003) survey study. However, ordinary people were presenting in 44 out of 180 news item; the findings do not consistent with the importance order among four variables in previous Ramprasad and Kelly's (2003) findings.

Fifth research question was correlated with the previous aforementioned research questions which is designed to know the priority order of Nepalese journalists' democracy related news item among four variables: 1) providing analysis and interpretation of complex problem; 2) providing accurate information in a timely manner; 3) investigating claims and statements made by the governments; and 4) giving ordinary people a chance to express views to public affairs. The purpose of this research question was to find out the democracy related news items variables that Nepalese journalists consider importance in their news coverage for enhancement of democracy. Previous research of Weaver and Willhoit's study show that American journalists give more importance to provide analysis and interpretation of complex problem first, then following by providing accurate information in a timely manner, investigating claims and statements made by the governments, and giving ordinary people a chance to express views to public affairs respectively(1996).

The present study analysed news items and found that Nepalese journalists give more importance to provide accurate information in a timely manner in their news coverage. This item captured $67 \%$ out of 180 news stories. The second important variable was to provide analysis and interpretation of complex problem in news coverage. This item captured $65 \%$ news that related to this variable in total news stories.

Similarly, the variable investigating claims and statements made by the governments, ranked third important item among the four variables. $29 \%$ news was found on this category. Finally, the less presence out of the total four variables was to give ordinary people a chance to express views to public affairs. This variable captured only $24 \%$ out of total news stories. The 
priority order of the variables can be seen below in the table 1 and figure 2.

\section{Table 1}

Democracy Related News Items in Priority Order in the News Coverage of Nepal

\begin{tabular}{lll} 
Variables & $\begin{array}{l}\text { Total news } \\
(\mathrm{n}=180)\end{array}$ & $\begin{array}{l}\text { Percentage } \\
100 \%\end{array}$ \\
\hline
\end{tabular}

Provide accurate information in a timely manner $120 \quad 67$

Provide analysis and interpretation of complex problem $117 \quad 65$ Investigate claims and statements made by the governments

$53 \quad 29$

Give ordinary people a chance to express views to public affairs

$44 \quad 24$

News source: Kantipur and Nagarik Publication date: 1-15 March, 2010

Figure 2 Nepalese Journalists' Democracy Related News Coverage Items

\section{Nepalese journalists' democracy related coverage items priority order (in per cent)}

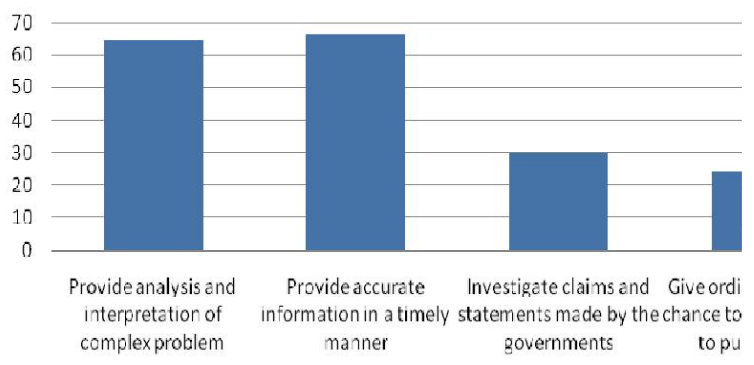


News source: Kantipur and Nagarik; Publication date: 1-15 March, 2010.

The above table and figure show that Nepalese journalists consider almost equal importance to democracy related two variables such as providing analysis and interpretation of complex problem, and providing accurate information in a timely manner. News coverage shows the following results of each variable as 117 and 120 out of total 180 news stories respectively. Investigating claims and statements made by the government and the giving ordinary people a chance to express views to public are two variables that correspond as 53 and 44 news items out of 180 news stories respectively.

However, Ramprasad and Kelly (2003) note that Nepalese journalists perceived the following democracy related news items as: they follow the news items of providing accurate information in a timely manner (1.25 mean score); giving ordinary people a chance to express views on public affairs (1.48 mean score); providing analysis and interpretation of complex problems (1.61 mean score); and, investigating claims and statements made by the government (1.79 mean score). (Here, lower mean score point indicate high priority and each variables were calculated with 1-5 scale point).

\section{Nepalese Journalists' Democracy Related News Item Variables in Priority Order}

Figure 3 below is a combining picture of journalists' perceived and corresponding democracy related news item variables. The figure shows that there have similar implications in their news coverage pattern in both past (2003) and present (2010) situation. However, give ordinary people a chance to express views to public affairs moved to fourth priority order in journalists' corresponding news items variables which was in second priority order in their perceived importance. Among other three variables: provide accurate information in a timely manner is a non-mover variable that positioned at first priority order in journalists' both perceived and corresponding 
democracy related news item variables. Rest two variables as provide analysis and interpretation of complex problem, and investigate claims and statements made by the governments; moved upward position from third and fourth of journalists' perceived priority order to second and third position in corresponding news item variables in the news coverage.

Figure 3
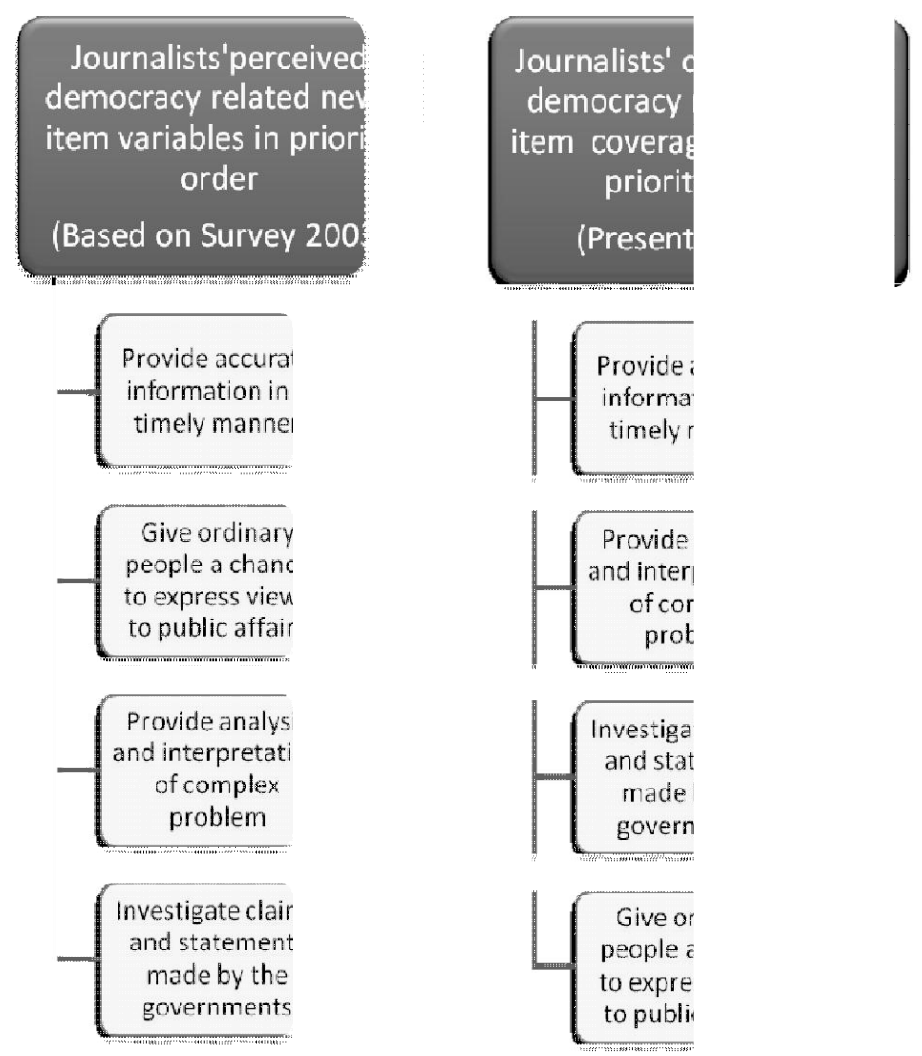

\section{Sources:}

1. News from Kantipur and Nagarik 1-15 March, 2010; for journalists' corresponding democracy-related news items variables (based on content analysis) 
2. A Survey Study of Nepalese Journalists' by Ramprasad and Kelly (2003) for journalists' perceived democracy related news items variables

\section{Discussion}

After combining the output of two Nepalese representative national vernaculars -Kantipur and Nagarik - published within $1^{\text {st }}$ March to $15^{\text {th }}$ March, 2010; the study found 180 news articles related to Constitution Assembly issue. Those articles were extracted and coded for further analysis. The analysis was done in four variables dimensions such as providing analysis and interpretation of complex problem; providing accurate information in a timely manner; investigating claims and statements made by the governments; and giving ordinary people a chance to express views to public affairs.

Previous study of Weaver and Wilhoit's (1996) survey on American journalists identified the following correlation between these news variables and journalists' perceived roles. Accordingly, journalists' interpretative role consists of providing analysis and interpretation of complex problem. In disseminator role journalists' primary duty is to get information to the public as quickly and accurately as possible. Journalists' investigative or adversarial role inspired them to investigate stories made by the government and provide their readers with analysis of complex issues. The populist mobilizer or advocate role consists of letting ordinary people express views getting involved in the news.

The present study of Nepalese journalists perceived roles in their news coverage during the above given period indicates that these news variables were rarely pay equal attention to them. Out of 180 news articles related to Constitution Assembly issue $65 \%$ coverage was providing analysis and interpretation of complex problem. $67 \%$ news articles were related to providing accurate information in a timely manner. The variable of investigating claims and statements made by the 
governments captured only $29 \%$; and giving ordinary people a chance to express views on public affairs was $24 \%$.

In other words, however, all news articles were democracy related; there was a significant difference marked in terms of priority order in between these variables. Democracy related two variables such as providing analysis and interpretation of complex problem and providing accurate information in a timely manner perceived high importance for Nepalese journalists in their coverage. Both variables captured equal importance with a minimal difference as 117 and 120 out of 180 news articles respectively. On the other hand, Nepalese journalists perceived less importance to the variables such as investigating claims and statements made by the governments and giving ordinary people a chance to express views on public affairs in theirs news content. Only 53 and 44 news items were captured in these variables respectively.

Hence, the investigation provides a sufficient ground to discuss Nepalese journalists' perceived role corresponds in their coverage. Evidence shows that journalists give more importance to interpreter and disseminator roles in their news coverage. It is also consistent with previous survey findings of Ramprasad and Kelly (2003). Following by adversarial role, which is constantly remain in third priority in both previous and the present study on their role perceptions. Unlike previous survey only populist mobilizer or advocate role, Nepalese journalists do not give importance as they uttered in their previous survey questionnaire of 2003. Hence, Nepalese case study reveals some important findings such as it supports the hypothesis of gatekeeping theory as journalists perceived roles affects the news coverage (Shoemaker and Reese, 1996).

News coverage show that Nepalese journalists' give disseminator role as the most important and it consists with the news variable as providing accurate information in a timely manner. Scholars believe that accuracy and timeliness are fundamental to journalistic practice the world over. In Nepalese case, journalists' professional Code of Ethics might be the 
influencing factors to provide accurate and timely information. Journalists' ethical roles influenced them to follow the moral values based on principles of right and wrong (Altschull, 1990, p. 357). The item accurate and timely information also scored highly in all the American Journalist studies (cited in Ramprasad and Kelly, 2003, p. 305). Altschull (1990) describes that an early conception of journalistic ethics was to serve humanity rather than to seek the journalist's own ends (p. 359). Many news media published standards governing how their staffs should operate (Black, 1992). Society of Professional Journalists Code of Ethics state the duty of journalists is to serve the truth and for this purpose they believe the responsibilities of journalists is to carry obligations that require journalists to perform with intelligence, objectivity, accuracy and fairness (cited in Shoemaker and Reese, 1996, p. 357).

The trend of timely information was also observed as the high importance among Ugandan journalists. However, the study was conducted with survey questionnaire; Peter G. Mwesige's (2004) study on Uganda's journalists found that getting information out quickly was the highest rated media function, supported by 86 per cent of the respondents.

Research on professional values and norms also attempts to ascertain how journalists themselves identify the most significant occupational values. The research findings show that there are various professional values that tend to influence journalists to follow their roles (Shoemaker and Reese, 1996). Weaver (1998) survey of the USA-based working journalists reveals that 'objectivity' as the single most important professional value. Preston (2009) suggests that objectivity as a core value is often seen to match up closely with the neutral model of journalism and the notion of 'balanced' reporting. Scholars suggest that the preference for 'objectivity' also neatly matches the master logic of commercial media organizations, as partisanship might put off the potential appeal to advertisers or audiences (McManus, 1997; Weaver, 1998; McQuail, 2000). Keeping the public-up-to-date with news/information is another 
key value that journalists tended to follow (Shoemaker and Reese, 1996).

Similarly, the investigation provides a sufficient ground to discuss Nepalese journalists' enhancing transitional democracy with their interpretative role. News coverage pattern indicate that they give second most important to interpretative roles which encourage them to provide analytical coverage evaluating pros and cons of the reporting with interpreting complex problem as well. However, little evidence suggests the possibilities of high importance to interpretive role; there is not any clear correlation of journalists' adoptions of such type of western model of interpretive journalistic practice. The interpretive role conception has for the past several decades been a major part of what Weaver and Wilhoit (1996) have called 'journalism's majority culture' in western media culture (p. 138). Schudson (2003) said 'interpretative journalism' first came into vague in the 1930s when journalists expressed concern that the world had become very complex and it was their duty to help readers make sense of it. He also noted that this concern had nothing to do with 'partisan sentiment' among journalists (p. 84).

Peter G. Mwesige (2004, p. 84) study on Ugandan journalists also found that they support the interpretative roles of the news media. However, several Nepalese journalists primarily do not possesses to educational qualification from universities; their experience over two decades on democratic environment of the political upheaval situation and threat over journalism practices from military forces as well as revolutionary groups might be inspired them to socialize interpretative role for establishment of peace and democracy interpreting complex issue such as federalism, republicanism, secularism, inclusion, minorities and other issues that related to Constitution Assembly in their coverage.

Evidence show that when journalists come to covering of government, law, war, peace, poverty, and such, journalists generally can be trusted to raise questions and demand 
verification in their quests for the truth in the news; but, stories of the paranormal, of the other-worldly, or religious matter they often seem to suspend critical judgement (Triplett, 1993, p. 33). Nevertheless to say, Nepalese journalists perceived their roles as an educator for enhancement of democracy (Ramprasad \& Kelly, 2003). Their educational role might be an influencing factor to cover interpreting the high important issue such as Constitution Assembly for educating purpose to mass audiences. Likewise, Nepalese journalists still considered as their primary duty is to fulfil social responsibility (Adhikari, 2008). Michael Schudson (2008) describes the social responsibility role of journalists as the root of interpretative style of American journalism. When society became vulnerable and complex in terms of changing social norms and values with modern development journalists feel their responsibility is to serve the society rather than just reporting (Schudson, 2008). Thus, it can be noted that very recently changing socio political scenario, for instance, from monarchy to republican state of Nepal since second Political Movement (2006) might be assisting to journalists to follow the interpretative type of reporting with social responsibility norms. It is also interesting that however, coverage style do not mark with commentary, gossip and opinionated; but it can be noted that Nepalese journalists follow the coverage with interpreting the issue and the events rather than just describing it.

Nepalese journalists give less importance to adversarial or investigative and advocate or populist mobilizer role in their news coverage. As already mentioned the investigative role that consists with the news variable of investigating claims and statements made by the governments secured only $29 \%$ in total 180 news items. Previous findings revealed that adversarial supporters were more likely to be older and experienced males, married, and members of a union. In a case study of Brazil, data suggest that the older journalists, who had experienced military rule and were politically aligned with the left, felt more at ease with taking an adversarial role. But, in Nepalese case, most of the journalists have no experienced with military services as well as they prefer to be liberal rather aligning with the left 
political parties (Ramprasad \& Kelly, 2003). Furthermore, there are $40 \%$ journalists below 29 years of age. Thus, journalists such consistencies might be the possible analysis in terms of less importance of adversarial role in their news coverage. Weaver and Wilhoit's (1996) survey study on American journalists also found that adversarial role is a minor concerned for them.

The final role conception is populist mobilizer and it consists with the news variable of giving ordinary people a chance to express views on public affairs. It is surprising that this item secured the lowest priority concerned among four variables that was $24 \%$ in total 180 news items. Actually, this dimension had captured as the second highest priority order among four variables in previous survey of Nepalese journalists' role perceptions (Ramprasad and Kelly, 2003). However, there is not any possible explanation behind the reverse findings; previous researches in other countries show that journalists' professional attitudes can be segmented into different variables. For instance, journalists who agreed that media should influence public opinion were also likely to embrace the adversarial roles (Weaver and Wilhoit, 1986). In Nepalese case too, however, journalists perceived advocate role as the primary concerned, their perceived role corresponding might be consisted with the adversarial role where they give less space to cover ordinary people a chance to express views on public affairs. The Nepalese journalists' ratting of this variable was significantly lower than other item and the finding is similar to the previous study of American journalists (Weaver and Wilhoit, 1996).

Weaver and his colleagues had examined factors influencing such role conceptions in their 21 countries journalism practices (1998). Their finding was that journalists working in smaller organizations were likely to embrace the populist mobilizer role. Hence, in Nepalese case too, journalists' indifference to give more space to ordinary citizens perhaps might be the cause of increasing news media organizational structure. Actually, the examined contents were representing from big media houses - 
the Kantipur Publications and the Nepal Republic Private Limited - in terms of nationwide circulation and cross-media ownership structure in Nepalese context.

From Nepalese case study on news coverage practice- perhaps the most important finding of this study is that Nepalese journalists highly value journalistic functions of information dissemination and interpretation of complex problems analysing the issues and agendas in their coverage. Some might have argued that Nepalese journalists are still beholden to the notion of development journalism that was prevalent in the 1970s. As already pointed out, this study did not investigate about journalism and national development. However, even if such investigation had been formed, and the news content had shown support for national development, it would not have subtracted from the evidence that Nepalese journalists do not see themselves as working for the patronizing outlets that development journalism inevitably led to. Rather, they seem to have embraced a conceptualization of independent journalism at the core of which is information, analysis and interpretation, as well as giving ordinary people a voice. Again, this has important implications for democratization, for the media cannot rise up to the challenges of popular participation and accountability of the state to the citizenry when those who work in journalism do not have a commitment to those roles that make the media central to democracy.

Nevertheless the Nepalese journalists, unsurprisingly, saw their roles similar to the roles played by journalists in western democracies. However, this study is not concerned to analyse the consequences of Nepalese journalists with western journalism practices. There are several reasons can be explained behind the cause of following western model of journalism, for instance, recently developed increasing number of media organizations scenario in media landscape of Nepal due to deregularisation, privatization, and commercialization might be discussing factors as the consequences of journalists' professionalism development. Future investigation can be a significant area of study on this regard. 
Hence, Nepalese journalists, however, the degree of journalism practices in terms of professionalism, content variation and technology adjustments are apparently differences and possess low quality comparatively to western journalistic practices; they follow western journalism practices in their news coverage. In sum, Nepalese journalists' news coverage pattern reveals that they give more importance to their roles in the following order as disseminator, interpreter, adversarial and populist mobilizer for enhancement of democracy.

\section{Conclusions}

Nepal has earned a peer attention due to its increasing relationship between journalism practices and political system. However, the constitution of Nepal guaranteed press freedom in 1990; the period could not mark satisfactorily. On the one hand, during insurgency (1996-2006) period around two dozen journalists were killed, many kidnapped and those who covered the news were also under the threat of political extremists or government's army (Adhikari, 2008). On the other hand, this is the important period, when private owned media including Radio, Television and Newspaper, spurned in a great number across the country. Privatization, deregularization and commercialization on media system established journalists' activities as a competitive profession in the country. It is obvious that how Nepalese journalism will be studied in such contrasting situation might be an interesting investigative topic. Thus, as a case study this research has focused to investigate whether there is a correspondence between roles that Nepalese journalists consider importance and the content of Nepalese journalism.

In this study, news contents of Kantipur and Nagarik were selected as representative news of their nationwide coverage. Constitution Assembly related issues were analysed for acknowledgement of journalists' democracy building roles with four variables as providing interpretation and complex problem; providing accurate information in a timely manner; investigating statements and claims made by the governments; 
and, giving ordinary people a chance to express views to public affairs in news coverage.

Before drawing conclusions, it is important to consider the following points here, in terms of the understanding the research conclusion. First important note is that there are no previous research studies have conducted in terms of the journalists' role perceptions and their news coverage pattern in Nepalese journalism. Second, the present case study analysed only the news content of special issue of Constitution Assembly; though it was the most concerning matter for political leaders as well as entire citizens including journalists. Third, due to unavailability of recent data of journalists' demographic, work-related and attitudinal profile, the present study analysed the result with available secondary data that is almost a decade old survey findings of Nepalese journalists' professional role perceptions by Ramprasad and Kelly (2003). Therefore, we should be careful not to overstretch the significance of the results of this study. Yet, we can make several important conclusions.

Nepalese case study shows that there is a noteworthy correspondence between the roles that Nepalese journalists consider importance and the content of Nepalese journalism. This finding also support the hypothesis of gatekeeping theory as individual journalists' role perceptions may influence media content (Shoemaker and Reese, 1996).

The research also found that Nepalese journalists give more importance to provide accurate and timely information, and interpretation of complex problems in terms of Constitution making issue in their coverage. Therefore, Nepalese journalists give more likely importance to their perceived disseminator role following by interpretive role in their coverage for enhancement of democracy. This finding is also similar journalism practices across the world (Weaver, 1998).

On the other hand, Nepalese journalists give less likely importance to investigating statements and claims made by the 
governments or political parties as well as giving ordinary people a chance to express views to public affairs in news coverage. Hence, Nepalese journalists perceived less likely to investigative or adversarial role and populist mobilizer or advocate role in their coverage.

\section{Notes}

1 Nepalese Journalist Code of Conduct - 1998 http://www.presscouncilnepal.org

2 Nepalese Journalists Code of Ethics - 2008, http://www.presscouncilnepal.org

\section{References}

Adhikari, D. (2008). Democracy can complicate the job of journalists. Nieman Reports, Boston: Harvard University, pp. 79-81.

Aditya, A. (1996). Mass Media and Democratization: A Country Study of Nepal. Kathmandu: Institute of Integrated Development Studies.

Altschull, H. J. (1984). Agents of Power. New York: Longman Altschull, J. H. (1990). From Milton to McLuhan: The ideas behind American Journalism. New York: Longman.

Bauer, R. (1964). The Communicator and the Audience. In L. A. Dexter \& D. M. White (Eds.), People, Society and Mass Communication (pp. 125-140). New York: Free Press.

Beam, R. A. (2008). The social characteristics of U.S. journalists and their 'Best Work'. Journalism Practice, 2: 1, 1-14

Belsey, A., and Chadwick, R. (1995). Ethics as a vehicle for media quality. European Journal of Communication 10, pp. 46173.

Berkowitz, D. and Limor, Y. (2003). Professional confidence and situational ethics- assessing the social-professional dialectic in journalistic ethics decisions. Journalism and Mass Communication Quarterly, 80 (4): 783-801.

Berelson, B. (1952) .Content Analysis in Communication Research. Glencoe, III: Free Press 1971(First edition from 1952). 
Black, J. (1992, November/December). Taking the pulse of the nation's news media. Quill, ppl 31, 33.

Breed, W. (1960). Social control in the newsroom: A functional analysis. In W. Schramm (Ed.), Mass Communications (pp. 178-194). Urbana: University of Illinois Press.

Breed Warren (1955). Social control in the newsroom: A functional analysis. Social Forces, 33, 326-335.

Buckalew, J. K. (1969). A Q-analysis of Television news editor's decisions. Journalism Quarterly, 46, 135-137.

Chambers, D., Linda, S., and Carole, F. (2004). Women and Journalism. London: Routledge.

Chibnall, S. (1981). The production of knowledge by crime reporters. In S. Cohen \& J. Young (Eds.), The Manufacture of News: Deviance, Social Problems, and the Mass Media (pp. 75-97). London: Constable.

Cook, T. E. (2005). The functions of the press in a democracy. In Overholser, Geneva \& Jamieson, Kathleen Hall (Eds.) The Press, New York: Oxford University Press.

Deuze, M. (2007) .Media Work. Cambridge: Polity.

Dimmick, J. (1974) .The gatekeeper: An uncertainty theory. Journalism Monographs, 37, 1-39.

Donbach, W. (2004).Psychology of news decisions: Factors behind journalists' professional behaviour. Journalism, 5(2), 131157.

Drew, D. G. (1975). Reporters' attitudes, expected meetings with social and journalistic objectivity. Journalism Quarterly, 52, 219-224.

Farley, J. (1978). Women's magazines and the equal rights amendment: Fiend or foe? Journal of Communication, 28(1), pp. 187-92.

Flegel, R. C., and Chaffee, S. H. (1971). Influences of editors, readers, and personal opinions on reporters. Journalism Quarterly, 48, 645-651.

Flynn, T. (2002). Source Credibility and Global Warming: A Content Analysis of Environmental Groups. Paper presented at the annual meeting of Association for Education in Journalism and Mass Communication.

Galtung, J., and Ruge, M. H. (1965). The structure of foreign news: The presentation of the Congo, Cuba, and Cyprus 
crises in four Norwegian newspapers. Journal of Peace Research 1: 64-91.

Gans, H. (1979). Deciding What's News. New York: Pantheon.

Gersh, D. (1992a, December 5) Ethics handbook. Editor \& Publishers; pp. 18-19, 37.

Gieber, W. and Johnson, W. (1961). The city hall beat: A study of reporter and source roles. Journalism Quarterly, 38, 289-297.

Gieber, W. (1960b). Two communicators of the news: A study of the roles of sources and reporters. Social Forces, 39, 7683.

Gitlin, T. (1980). The Whole World is Watching. Berkeley: University of California Press.

Goodrick, E. T. (1991). Editorial Writers: Approaches to selected women's issues. Newspaper Research Journal 12(3), pp. 20-31.

Gupta, A. (1993) Politics in Nepal 1950-60. Delhi: Kalinga.

Hallin, D. (2000). Commercialism and professionalism in the American news media. In J. Curran and M. Gurevitch (eds) Mass Media and Society - (3rd Ed), London: Arnold.Belsey and Chadwick, (1995).

Hamilton, J. T. (2004). All the News that's Fit to Sell. Princeton, NJ: Princeton University Press.

Herscovitz, H. G. (2004). Brazilian Journalists' perceptions of media roles, ethics and foreign influences on Brazilian journalism. Journalism Studies, 5: 1, 71-86

Holsti, O. R. (1969) .Content Analysis for the Social Sciences and Humanities. Reading, MA: Addison-Wesley.

Janowitz, M. (1975) .Professional models in journalism: The gatekeeper and the advocate. Journalism Quarterly, 52, pp. 618-626.

Johnstone, J. W. C., Slawski, E. J., \& Bowman, W.W. (1972). The professional values of American newsmen. Public Opinion Quarterly, 36, 303-312.

Johnstone, J. W.C., Slawski, E. J., and Bowman, W. W. (1976). The News People: A Sociological Portrait of American Journalists and Their Work. Urbana, IL: University of Illinois Press. 
Krippendorff, K. (2004). Content Analysis: An Introduction to Its Methodology. $2^{\text {nd }}$ edition, Thousand Oaks, CA: Sage Publications.

McCombs, M. E., \& Shaw, D. L. (1972) .The agenda-setting function of mass media. Public Opinion Quarterly, 36(2), 176-187.

Malla, B.C. (1983). Mass media: Tradition and change (an overview of change in Nepal). In Contributions to Nepalese Studies, vol. 10, No. 1-2 (pp. 69-79).

McManus, J. H. (1997). Who's responsible for journalism? Journal of Mass Media Ethics, 12 (1): 5-17.

McQuail, D. (2000). McQuail's Mass Communication Theory. $\left(4^{\text {th }}\right.$ Ed) Thousand Oaks, CA: Sage.

Molotch, H., and Lester. M. (1974). News as purposive behaviour: On the strategic use of routine events, accidents, and scandals. American Sociological Review 39: 101-112.

Mwesige, P. G. (2004). Disseminators, advocates and watchdogs. Journalism 5(1): 69-96.

Neuendorf, K. A. (2002). The Content Analysis Guidebook. Thousand Oaks, CA: Sage Publications.

Paletz D. L., and Entman, R. M. (1981) .Media, Power, Politics. New York: Free Press.

Paudyal, B. (1995) .Political news or news about politics. In Rijal, M. and Paudyal, B. (eds.) Ideas and Reflections. Kathmandu: Seminar Group.

Peiser, W. (2000). Setting the journalist agenda: Influences from journalists' individual characteristics and from media factors. Journalism \& Mass Communication Quarterly, $77(2), 243-257$.

Perry, D. K. (2002). Theory and Research in Mass Communication: Contexts and Consequences ( $2^{\text {nd }}$ ed.). Mahwah, N. J.: Lawrence Erlbaum.

Peterson, R. A., Albaum, G., Kozmetsky, G, \& Cunningham, I. C. M. (1984). Attitudes of newspaper business editors and general public toward capitalism. Journalism Quarterly, 61, 56-65.

Peterson, S. (1979) Foreign news gatekeepers and criteria of newsworthiness. Journalism Quarterly, 56, 116-125.

Pokhrel , G. P. and Koirala,, B. D. (1995) Mass Media Laws and Regulations in Nepal. Singapore: NPI and AMIC. 
Powers, A., and Fico, F. (1994) Influences on Reporters' Use of Sources at High Circulation U.S. Newspapers. Association for Education in Journalism and Mass Communication annual convention.

Press Council Nepal Report (2008) Audit of Media Circulation Report (Electronic Version) Retrived August 15, 2010 . http://www.presscouncilnepal.org/abc.php

Preston, P. (2009) Making the News: Journalism and News Cultures in Europe. New York: Routledge.

Ramprasad, J. and Kelly, J. D. (2003) Reporting the news from the world's rooftop: A survey of Nepalese journalists. Gazette, 65(3); 291-315

Reese, S. D., and Danielian, L. H. (1989) Inter-media influence and the drug issue: Converging on cocaine. In P. J. Shoemaker (Ed.), Communication Campaigns about Drugs. Government, Media, Public (pp. 29-46). Hillsdale, NJ: Lawrence Erlbaum.

Robinson , M. J. (1983) Just how liberal is the news? 1980 revisited. Public Opinion, pp. 55-60.

Ross, K. (2004) Sex at work: gender politics and newsroom culture. In Marjan de Bruin and Karen Ross (Eds.), Gender and Newsroom Culture: Identities at Work, Creskill, NJ: Hampton Press, pp. 143-60.

Savada, A. M. (1993) Nepal and Bhutan: Country Studies, $3^{\text {rd }}$ edn. Washington, DC: Federal Research Division, Library of Congress.

Schudson, M. (2003) The Sociology of News. New York: Norton.

Schudson, M. (2008) Why Democracies Need an Unlovable Press, Cambridge: Polity.

Shoemaker, P. J. (1991) Gatekeeping. Newbury Park, CA: Sage.

Shoemaker, P. J., \& Reese, S. D. (1996) Mediating the Message: Theories of Influences on Mass Media Content ( $2^{\text {nd }}$ ed.). White Plains, NY: Longman.

Shoemaker, J. P., and Cohen, A. A. (2006) News around the World. Routledge, New York.

Shoemaker, P. J., \& Vos, T. P. (2009) Gatekeeping Theory. New York / Abingdon: Routledge.

Shoemaker, P. J., Vos, T. P., and Reese, S. D. (2009) Journalists as gatekeepers. In Karin Wahl-Jorgensen, Thomas Hanitzsch 
(Eds.), The Handbook of Journalism Studies, Routledge, New York (pp. 73-87).

Sigal, L. (1973) Reporters and Officials: The Organization and Politics of News gathering. Lexington, MA: Heath.

Skewes, E. A. (2007) Message Control: How News is Made on the Presidential Campaign Trial. Lanham: Rowman and Littlefield Publishers, Inc.

Starck, K., and Soloski, J. (1977) Effect of reporter predisposition in covering controversial story. Journalism Quarterly, 54, 120-125.

Thapaliyal, s. (2006) Nepal at the political crossroads: Options for India. South Asian Survey, vol. 13 no. 1 (pp. 51-72).

Weaver, D. H. (1998) The Global Journalist: News People around the World. Cresskill, NJ: Hampton Press.

Weaver, D. H., and Wilhoit, G. C. (1991) The American Journalist: A Portrait of U.S. News People and their Work $\left(2^{\text {nd }}\right.$ ed.). Bloomington: Indiana University Press.

Weaver, D. H., and Wilhoit, G. C. (1996) The American Journalist in the 1990s. Bloomington, IN: Indiana University Press.

Weaver, D. H.; Beam, R. A., Brownlee, B. J., Voakes, P. S., \& Wilhoit , G. C. (2007) The American Journalist in the $21^{\text {st }}$ Century: U.S. News People at the Dawn of a New Millennium. Mahwahk, NJMErlbaum.

Weaver, H. D. and Wilhoit, C. G. (1986) The American Journalist. Bloomington, IL: Indiana University Press.

Weber, R. P. (1990) Basic Content Analysis ( $2^{\text {nd }}$ ed.). Newbury Park, CA.

White, D. M. (1950) The 'Gate keeper'. A case study in the selection of news. Journalism Quarterly, 27, 383-390.

The author is an Assistant Professor at the Department of Langauges and Mass Communication, School of Arts, Kathmandu University. 